\title{
EVALUASI KINERJA INSTALASI PENGOLAHAN AIR LIMBAH RSD MANGUSADA KABUPATEN BADUNG
}

\author{
Kadek Diana Harmayani \\ Program Studi Teknik Lingkungan, Fakultas Teknik, Universitas Udayana \\ Email :kdharmayani@unud.ac.id
}

\begin{abstract}
ABSTRAK: Rumah Sakit Umum Daerah (RSD) Mangusada sebagai penyedia fasilitas kesehatan tentunya menghasilkan limbah cair dalam setiap kegiatan operasionalnya. Air limbah pada Instalasi Pengolahan Air Limbah (IPAL) RSD Mangusada mengandung kandungan Biological Oxygen Demand $\left(\mathrm{BOD}_{5}\right)$, Chemical Oxygen Demand (COD), Total Suspended Solid (TSS), amonia, total coliform, Total Dissolved Solid (TDS), detergen, minyak dan lemak. Penelitian ini bertujuan untuk mengevaluasi kinerja dari IPAL serta mengetahui kandungan pada air limbah setelah diolah oleh IPAL RSD Mangusada sesuai dengan baku mutu acuan dari Peraturan Gubernur Bali No. 16 Tahun 2016 dan Peraturan Menteri Lingkungan Hidup dan Kehutanan Republik Indonesia Nomor: P.68/ Menlhk/Setjen/ Kum.1/8/2016. Sistem pengolahan air limbah di RSD Mangusada menggunakan sistem biologis. Data yang digunakan dalam analisis adalah data sekunder, yaitu data Bed Occupation Rate (BOR) bulan Juni 2020, jumlah tempat tidur total, debit rata-rata outlet bulan Juni 2020 serta parameter kualitas dan kuantitas air limbah di inlet dan outlet IPAL bulan Januari 2020 hingga Juli 2020. Berdasarkan hasil pengujian kualitas dan kuantitas air limbah pada outlet IPAL RSD Mangusada, kandungan air limbah yang terdapat pada outlet IPAL sesuai dengan standar peraturan baku mutu acuan. Selain itu, efektivitas dari efisiensi IPAL RSD Mangusada berhasil menurunkan kandungan amonia $92,35 \%, \mathrm{BOD}_{5} 64,03 \%$, COD 63,97\%, TSS 67,03\%, minyak dan lemak $64,64 \%$, total coliform 76,84\%, dan detergen sebesar 76,25\%. Tetapi efisiensi dari IPAL RSD Mangusada kurang baik dalam penurunan kandungan TDS sebesar $-3,92 \%$.
\end{abstract}

Kata Kunci: air limbah, instalasi pengolahan air limbah, efektivitas, RSD Mangusada.

\section{PERFORMANCE EVALUATION OF WASTE WATER TREATMENT INSTALLATION IN MANGUSADA REGIONAL GENERAL HOSPITAL OF BADUNG REGENCY}

\begin{abstract}
The Mangusada Regional General Hospital (RSD) as a provider of health facilities certainly produces liquid waste in every operational activity. Wastewater in the Wastewater Treatment Installation (WWTI) RSD Mangusada contains Biological Oxygen Demand (BOD 5 ), Chemical Oxygen Demand (COD), Total Suspended Solid (TSS), ammonia, total coliform, Total Dissolved Solid (TDS), detergent, oil and fat. This study aims to evaluate the performance of the WWTI as well as to determine the content in the wastewater after being treated by the IPAL RSD Mangusada according to the reference quality standards of the Governor of Bali Regulation No.16/2016 and Regulation of the Minister of Environment and Forestry of the Republic of Indonesia Number: P.68/Menlhk/Setjen/Kum.1/8/2016. The wastewater treatment system at RSD Mangusada uses a biological system. The data used in the analysis are secondary data, namely the Bed Occupation Rate (BOR) data in June 2020, the total number of beds, the average discharge of outlets in June 2020 and parameters of the quality and quantity of wastewater in the inlet and outlet of WWTI from January 2020 to July 2020. Based on the results of testing the quality and quantity of wastewater at the WWTI of RSD Mangusada outlet, the content of waste water in the outlet of WWTI is in accordance with the regulatory standards for the reference quality standards. In addition, the effectiveness of the efficiency of the WWTI at RSD Mangusada succeeded in reducing the ammonia content of $92.35 \%, B O D_{5}$ $64.03 \%$, COD $63.97 \%$, TSS $67.03 \%$, oil and fat $64.64 \%$, total coliform $76.84 \%$. , and detergent at $76.25 \%$. But the efficiency of the WWTI of RSD Mangusada was not good enough in reducing the TDS content of $-3.92 \%$.
\end{abstract}

Keywords: wastewater, Wastewater Treatment Installation, effectiveness, RSD Mangusada. 


\section{PENDAHULUAN}

Limbah cair pada RSD Mangusada Kabupaten Badung mengandung parameter pencemar seperti Biological Oxygen Demand $\left(\mathrm{BOD}_{5}\right)$, minyak dan lemak, amonia, Total Coliform, Total Dissolved Solid (TDS), detergen dan lain-lain (RSD Mangusada, 2020). Menurut Mulyati dan Narhadi (2016), air limbah rumah sakit merupakan salah satu sumber pencemaran lingkungan yang memberi dampak negatif berupa gangguan kesehatan, maka perlu adanya tindakan pengecekan terhadap kualitas air limbah pada bagian outlet IPAL RSD Mangusada dan dibandingkan dengan baku mutu dari Peraturan Gubernur Bali No. 16 Tahun 2016 tentang baku mutu lingkungan hidup dan kriteria baku kerusakan lingkungan hidup, serta Peraturan Menteri Lingkungan Hidup dan Kehutanan Republik Indonesia Nomor: P.68/Menlhk/ Setjen/Kum.1/ 8/2016 tentang baku mutu air limbah domestik, sehingga diketahui hasil kualitas air limbah pada outlet IPAL apakah telah memenuhi syarat peraturan baku mutu yang menjadi acuan. Lalu perlu adanya tindakan evaluasi terhadap kinerja dari instalasi pengolahan air limbah (IPAL) di RSD Mangusada Kabupaten Badung guna mengetahui tingkat efektivitas kinerja IPAL terhadap efisiensi penurunan nilai konsentrasi dari parameter pencemar yang terkandung dalam air limbah, hal ini mengingat limbah medis termasuk ke dalam kategori limbah berbahaya dan beracun (limbah B3).

\section{MATERI DAN METODE}

\section{Air Limbah Rumah Sakit}

Menurut Subekti (2011), air limbah rumah sakit merupakan hasil dari berbagai macam kegiatan dan aktivitas rumah sakit yang berdampak buruk untuk lingkungan sekitar apabila tidak diolah dengan baik. Menurut Ningrum dan Khalista (2014), sumber limbah cair rumah sakit berasal dari limbah medis dan limbah non medis. Limbah dari kegiatan operasional rumah sakit tidak hanya berasal dari balai pengobatan dan tempat praktik dokter saja, tetapi juga dihasilkan dari unit-unit penunjang lainnya, seperti ruang operasi, farmasi, dapur, laundry, tempat pengolahan sampah, serta tempat penyelenggaraan pendidikan dan pelatihan Djaja dan Maniksulistya (2006).

\section{Baku Mutu Air Limbah}

Peraturan perundang-undangan yang mengatur mengenai limbah cair pada rumah sakit meliputi peraturan mengenai baku mutu limbah cair rumah sakit di Indonesia khususnya RSD Mangusada Kabupaten Badung. Peraturan tersebut adalah PERGUB Bali No. 16 Tahun 2016 tentang baku mutu lingkungan hidup dan kriteria baku kerusakan lingkungan hidup, serta PERMEN LHK Republik Indonesia Nomor: P.68/Menlhk/Setjen/Kum.1/8/2016 tentang baku mutu air limbah domestik. Baku mutu air limbah pada kegiatan pelayanan kesehatan bisa dilihat pada Tabel 1.

Tabel 1. Standar Baku Mutu Air Limbah Pada Kegiatan Pelayanan Kesehatan

\begin{tabular}{|c|c|c|c|c|}
\hline \multirow[b]{2}{*}{ No } & \multirow[b]{2}{*}{$\begin{array}{c}\text { Paramet } \\
\text { er }\end{array}$} & \multirow[b]{2}{*}{$\begin{array}{l}\text { Sat } \\
\text { uan }\end{array}$} & \multicolumn{2}{|c|}{ Nilai Maksimum } \\
\hline & & & $\begin{array}{l}\text { PerGub } \\
\text { Bali No. } \\
16 / 2016\end{array}$ & $\begin{array}{c}\text { PerMen } \\
\text { LHK } \\
\text { No } \\
\text { P.68/201 } \\
6 \\
\end{array}$ \\
\hline 1 & Suhu & ${ }^{\circ} \mathrm{C}$ & 38 & - \\
\hline 2 & TDS & $\begin{array}{c}\mathrm{mg} / \\
\mathrm{L}\end{array}$ & 2000 & - \\
\hline 3 & TSS & $\begin{array}{c}\mathrm{mg} / \\
\mathrm{L}\end{array}$ & 200 & 30 \\
\hline 4 & $\mathrm{pH}$ & - & $6-9$ & $6-9$ \\
\hline 5 & COD & $\begin{array}{c}\mathrm{mg} / \\
\mathrm{L}\end{array}$ & 80 & 100 \\
\hline 6 & Detergen & $\begin{array}{c}\mathrm{mg} / \\
\mathrm{L}\end{array}$ & 10 & - \\
\hline 7 & Amonia & $\begin{array}{c}\mathrm{mg} / \\
\mathrm{L}\end{array}$ & 10 & 10 \\
\hline 8 & BOD & $\begin{array}{c}\mathrm{mg} / \\
\mathrm{L}\end{array}$ & 50 & 30 \\
\hline 9 & $\begin{array}{l}\text { Minyak } \\
\text { dan } \\
\text { lemak }\end{array}$ & $\begin{array}{c}\mathrm{mg} / \\
\mathrm{L}\end{array}$ & 10 & 5 \\
\hline 10 & $\begin{array}{l}\text { Total } \\
\text { coliform }\end{array}$ & $\begin{array}{c}\mathrm{MP} \\
\mathrm{N} / \\
100 \\
\mathrm{~mL}\end{array}$ & 5000 & 3000 \\
\hline
\end{tabular}

Sumber: Peraturan Gubernur Bali. (2016) dan PERMEN LHK Republik Indonesia Nomor: P.68/Menlhk/Setjen/Kum.1/8/2016

\section{Jumlah Kebutuhan Air Bersih}

Berdasarkan Keputusan Menteri Kesehatan Nomor:1204/MENKES/SK/X/2004 bahwa kebutuhan air bersih untuk fasilitas 
sanitasi di rumah sakit yaitu 500 liter/TT/hari. Kebutuhan air bersih ini harus terpenuhi sehingga dapat mencukupi semua kegiatan medis dan nonmedis. Jumlah kebutuhan air bersih yang dibutuhkan untuk kegiatan instalasi laboratorium, instalasi rawat, jalan instalasi rawat inap, kamar jenazah, dapur, laundry, ruang operasi, dan jumlah pasien atau pengunjung yang berobat di rumah sakit yang menggunakan air bersih untuk kegiatan mandi atau keperluan lainnya. Debit air limbah yang masuk ke unit IPAL bisa ditentukan berdasarkan jumlah tempat tidur (BOR). Metode ini merupakan metode yang paling umum digunakan dalam menghitung debit aliran limbah cair rumah sakit (Yenti, 2011).

\section{Tahapan Penelitian}

Penelitian ini mengikuti tahapan yang dijabarkan pada bagan alir Gambar 1. Dimana dimulai dengan pemilihan topic, kemudian dilanjutkan dengan melakukan studi literatur. Pengumpulan data primer dilakukan dengan wawancara dan observasi lapangan sedangkan data sekunder berupa Bed Occupation Rate (BOR), jumlah tempat tidur, debit rata-rata di outlet bulan Juni 2020, dan parameter kualitas dan kuantitas air limbar pada inlet dan outlet IPAL. Analisis data dilakukan dengan Menganalisa kapasitas terpakai IPAL RSD Mangusada pada bulan Juni 2020, menganalisa Kualitas outlet air limbah RSD Mangusada dengan membandingkan dengan baku mutu acuan, evaluasi Efektivitas Kinerja Pengolahan Air Limbah pada IPAL RSD Mangusada dengan membandingkan parameter air limbah di inlet dan outlet.

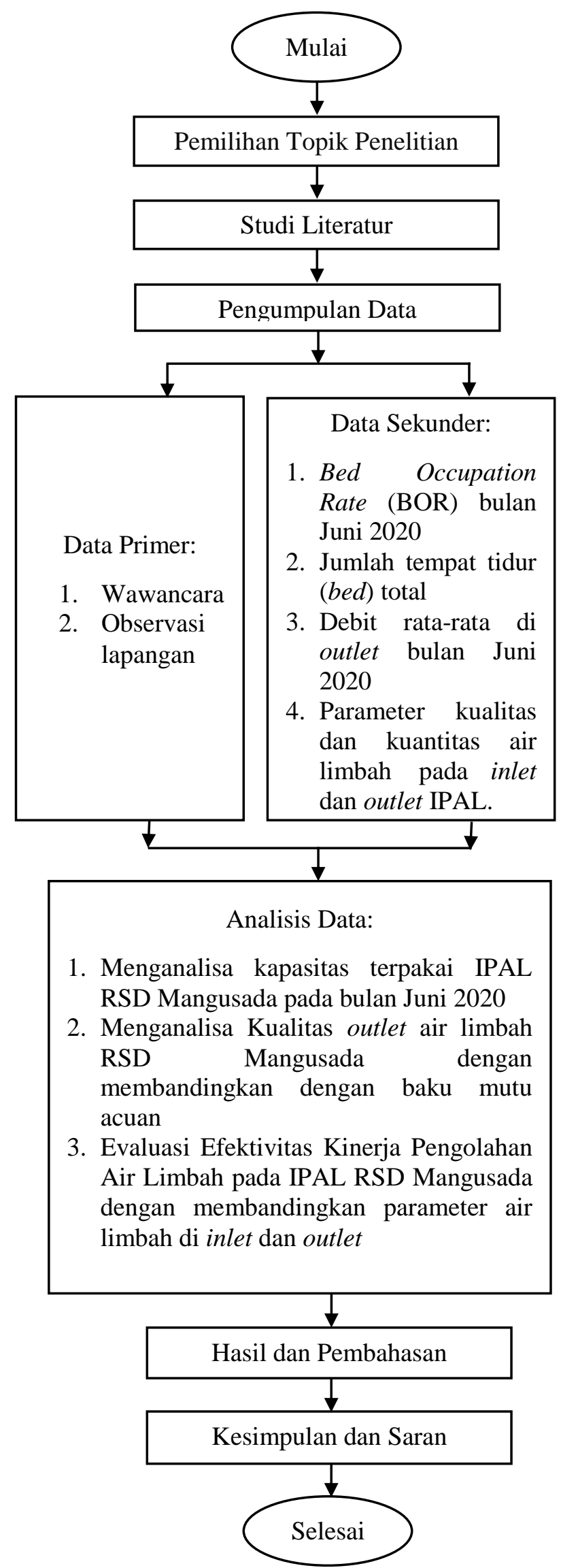

Gambar 1. Kerangka Penelitian 
HASIL DAN PEMBAHASAN

\section{Proses Pengolahan Air Limbah RSD Mangusada}

Proses Pengolahan Air Limbah yang diterapkan pada IPAL RSD Mangusada adalah pengolahan air limbah dengan sistem biologis. Sebelum air limbah diolah pada bagian IPAL, air limbah terlebih dahulu melewati septiktank atau bak penangkap lemak lalu menuju ke IPAL. Hal ini dikarenakan lemak dan minyak merupakan bahan organis bersifat tetap dan sukar diuraikan bakteri (Ayuningtyas (2009). Jadi saat air limbah mengalir menuju IPAL, air limbah sudah melalui proses pengendapan di septitank atau bak penangkap lemak, kemudian masuk ke bagian bak anaerobic processor pada bagian awal IPAL untuk melalui proses pengendapan awal. Air limbah yang ada dalam bak equalisasi mengalir menuju bagian selanjutnya untuk diolah secara lengkap, yakni secara kimia, fisik dan biologis. Berikut pada gambar 2 diperlihatkan skema alur air limbah pada IPAL RSD Mangusada Kabupaten Badung.

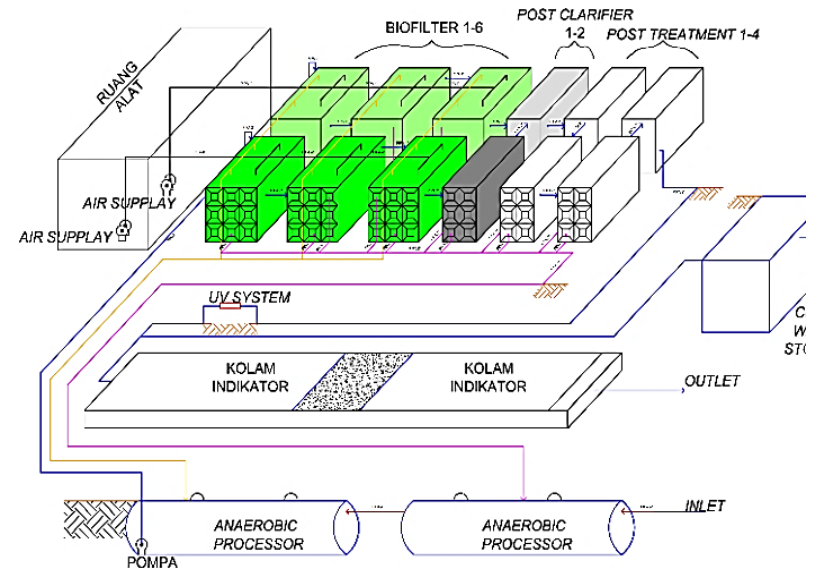

Gambar 2. Skema Alur Air Limbah pada IPAL RSD Mangusada (Sumber: RSD Mangusada, 2019)

\section{Analisis Kapasitas IPAL berdasarkan Konsumsi Air Bersih}

Berdasarkan data sekunder bahwa tingkat hunian (BOR) rumah sakit bulan Juni 2020 adalah $67,2 \%$ dan jumlah tempat tidur 231 buah. Perhitungan dari analisis kapasitas IPAL sebagai berikut:

Keperluan atau kebutuhan Air bersih Rumah Sakit $=500 \mathrm{lt} / \mathrm{TT} / \mathrm{hari}$

Debit outlet pada bulan Juni $=2.179 \mathrm{~m}^{3}(\mathrm{RSD}$

Mangusada, 2020)
Perhitungan :

Asumsi kebutuhan air bersih tiap tempat tidur $(\mathrm{TT})=500 \mathrm{lt} / \mathrm{bed} / \mathrm{hari}$

Penggunaan air bersih $=500$ liter $/$ hari $/ \mathrm{TT} \mathrm{x}$ 231 TT $x 67,2 \%=77616 \mathrm{~L} /$ hari atau 77,616 $\mathrm{m}^{3} /$ hari

Maka debit air limbah (asumsi bahwa debit air limbah $80 \%$ dari penggunaan air bersih) $=77,616 \mathrm{~m}^{3} /$ hari $\times 80 \%=62,09 \mathrm{~m}^{3} /$ hari

Dari hasil perhitungan debit limbah cair dengan konsumsi air bersih menggunakan BOR dan jumlah tempat tidur, terlihat bahwa debit limbah sangat kecil jika dibandingkan dengan data sekunder yang diperoleh dari pihak rumah sakit. Hal ini terjadi karena saat perhitungan debit timbulan air limbah menggunakan BOR dan jumlah tempat tidur ini, konsumsi air bersih yang digunakan oleh karyawan dan pasien rawat jalan tidak diperhitungkan, sehingga debit yang diperoleh sangat kecil. Maka untuk perhitungan selanjutnya, debit limbah cair yang akan digunakan adalah debit maksimum berdasarkan data dari pihak rumah sakit. Angka $73 \mathrm{~m}^{3} /$ hari cukup aman untuk mewakili angka debit berdasarkan perhitungan BOR dan jumlah tempat tidur. Berdasarkan debit timbulan limbah cair yang diperoleh dari pihak rumah sakit, diketahui bahwa timbulan limbah cair yang akan masuk ke unit IPAL adalah 73 $\mathrm{m}^{3} /$ hari. Hal ini masih lebih rendah jika dibandingkan dengan debit maksimum limbah cair yang dapat di tampung oleh unit IPAL, yaitu $200 \mathrm{~m}^{3} /$ hari. Maka Q desain (200 $\mathrm{m}^{3} /$ hari $)>$ Q lapangan $\left(73 \mathrm{~m}^{3} /\right.$ hari $)$. Dengan demikian, dapat disimpulkan bahwa kapasitas IPAL yang tersedia masih mencukupi untuk mengolah timbulan limbah cair yang dihasilkan. Hasil perhitungan kapasitas IPAL pada bulan Juni dapat dilihat pada Tabel 2. 
Tabel 2. Kapasitas IPAL terpakai pada bulan Juni 2020

\begin{tabular}{cccc}
\hline Tgl & $\begin{array}{c}\text { Kapasitas } \\
\text { Maks. } \\
\left.\text { IPAL }{\left(\mathbf{m}^{3}\right)}^{\mathbf{3}}\right)\end{array}$ & $\begin{array}{c}\text { Air } \\
\text { Limbah } \\
\text { dihasilkan } \\
\left(\mathbf{m}^{\mathbf{3}}\right)\end{array}$ & $\begin{array}{c}\text { Kapasitas } \\
\text { IPAL pada } \\
\text { bulan Juni } \\
(\mathbf{\%})\end{array}$ \\
\hline $\mathbf{1}$ & 200 & 77,5 & 38,75 \\
$\mathbf{2}$ & 200 & 77,5 & 38,75 \\
$\mathbf{3}$ & 200 & 80 & 40 \\
$\mathbf{4}$ & 200 & 71 & 35,5 \\
$\mathbf{5}$ & 200 & 79 & 39,5 \\
$\mathbf{6}$ & 200 & 75 & 37,5 \\
$\mathbf{7}$ & 200 & 76,5 & 38,25 \\
$\mathbf{8}$ & 200 & 76,5 & 38,25 \\
$\mathbf{9}$ & 200 & 79 & 39,5 \\
$\mathbf{1 0}$ & 200 & 72 & 36 \\
$\mathbf{1 1}$ & 200 & 75 & 37,5 \\
$\mathbf{1 2}$ & 200 & 78 & 39 \\
$\mathbf{1 3}$ & 200 & 74 & 37 \\
$\mathbf{1 4}$ & 200 & 70,5 & 35,25 \\
$\mathbf{1 5}$ & 200 & 70,5 & 35,25 \\
$\mathbf{1 6}$ & 200 & 73 & 36,5 \\
$\mathbf{1 7}$ & 200 & 69 & 34,5 \\
$\mathbf{1 8}$ & 200 & 66 & 33 \\
$\mathbf{1 9}$ & 200 & 67 & 33,5 \\
$\mathbf{2 0}$ & 200 & 74 & 37 \\
$\mathbf{2 1}$ & 200 & 71,5 & 35,75 \\
$\mathbf{2 2}$ & 200 & 71,5 & 35,75 \\
$\mathbf{2 3}$ & 200 & 77 & 38,5 \\
$\mathbf{2 4}$ & 200 & 72 & 36 \\
$\mathbf{2 5}$ & 200 & 75 & 37,5 \\
$\mathbf{2 6}$ & 200 & 67 & 33,5 \\
$\mathbf{2 7}$ & 200 & 64 & 32 \\
$\mathbf{2 8}$ & 200 & 65 & 32,5 \\
$\mathbf{2 9}$ & 200 & 65 & 32,5 \\
$\mathbf{3 0}$ & 200 & 70 & 35 \\
\hline Total Debit & $\mathbf{2 1 7 9}$ & \\
\hline Rata-rata/Hari & $\mathbf{7 3}$ & $\mathbf{3 6 , 5}$ \\
\hline & & & \\
\hline
\end{tabular}

Perbandingan Kualitas Mutu Air Limbah Tiap Parameter pada Outlet IPAL RSD Mangusada dengan Baku Mutu Acuan

Kandungan parameter pada air limbah adalah pH, Biological Oxygen Demand $\left(\mathrm{BOD}_{5}\right)$, Chemical Oxygen Demand (COD), Total Suspended Solid (TSS), minyak dan lemak, amonia, total coliform, suhu, Total Dissolved Solid (TDS), dan detergen. Kandungan pada outlet setelah pengolahan air limbah harus sesuai dengan peraturan baku mutu acuan dari PERGUB Bali No. 16 Tahun 2016 tentang baku mutu lingkungan hidup dan kriteria baku kerusakan lingkungan hidup serta
PERMEN LHK Republik Indonesia Nomor: P.68/Menlhk/Setjen/Kum.1/8/2016 tentang baku mutu air limbah domestik, maka dapat dikatakan aman apabila sesuai baku mutu dan jika sebaliknya dapat dikatakan tidak aman. Berikut pada Tabel 3 bisa dilihat pengukuran tiap parameter pada bagian outlet IPAL.

Tabel 3. Kandungan tiap parameter pada outlet IPAL RSD Mangusada tahun 2020

\begin{tabular}{|c|c|c|c|}
\hline No & \multicolumn{3}{|c|}{ PARAMETER } \\
\hline \multirow[t]{14}{*}{1} & \multicolumn{3}{|l|}{ pH } \\
\hline & \multicolumn{2}{|c|}{ Baku Mutu } & Nilai \\
\hline & \multirow{2}{*}{$\begin{array}{l}\text { PERGUB } \\
\text { Bali } \\
\text { No.16/2016 }\end{array}$} & $\max$ & 9 \\
\hline & & $\min$ & 6 \\
\hline & \multirow{2}{*}{$\begin{array}{l}\text { PERMEN } \\
\text { LHK No } \\
\text { P.68/2016 }\end{array}$} & $\max$ & 9 \\
\hline & & $\min$ & 6 \\
\hline & Bulan & $\begin{array}{c}\text { Jumlah } \\
\text { Kandungan } \\
\text { outlet }\end{array}$ & Keterangan \\
\hline & Januari & 7,4 & Aman \\
\hline & Februari & 7 & Aman \\
\hline & Maret & 8,1 & Aman \\
\hline & April & 7 & Aman \\
\hline & Mei & 8 & Aman \\
\hline & Juni & 7,2 & Aman \\
\hline & Juli & 7,8 & Aman \\
\hline \multirow[t]{4}{*}{2} & \multicolumn{3}{|c|}{ Biological Oxygen Demand $\left(\mathrm{BOD}_{5}\right)$} \\
\hline & \multicolumn{2}{|c|}{ Baku Mutu } & $\begin{array}{l}\text { Kandungan } \\
\text { Maksimum }\end{array}$ \\
\hline & \multicolumn{2}{|c|}{ PERGUB Bali No.16/2016 } & 50 \\
\hline & \multicolumn{2}{|c|}{$\begin{array}{l}\text { PERMEN LHK No } \\
\text { P.68/2016 }\end{array}$} & 30 \\
\hline
\end{tabular}

\begin{tabular}{lcc}
\hline Bulan & $\begin{array}{c}\text { Jumlah } \\
\text { Kandungan } \\
\text { outlet }(\mathbf{m g} / \mathbf{L})\end{array}$ & Keterangan \\
\hline Januari & 4 & Aman \\
Februari & 3 & Aman \\
Maret & 2 & Aman \\
April & 3 & Aman \\
Mei & 9 & Aman \\
Juni & 14 & Aman \\
Juli & 2 & Aman \\
\hline
\end{tabular}




\begin{tabular}{|c|c|c|c|}
\hline 3 & \multicolumn{3}{|c|}{ Chemical Oxygen Demand (COD) } \\
\hline & \multicolumn{2}{|c|}{ Baku Mutu } & $\begin{array}{l}\text { Kandungan } \\
\text { Maksimum }\end{array}$ \\
\hline & \multirow{2}{*}{\multicolumn{2}{|c|}{$\begin{array}{l}\text { PERGUB Bali No.16/2016 } \\
\text { PERMEN LHK No } \\
\text { P.68/2016 }\end{array}$}} & 80 \\
\hline & & & 100 \\
\hline & Bulan & $\begin{array}{c}\text { Jumlah } \\
\text { Kandungan } \\
\text { outlet }(\mathrm{mg} / \mathrm{L})\end{array}$ & Keterangan \\
\hline & Januari & 19 & Aman \\
\hline & Februari & 13 & Aman \\
\hline & Maret & 8 & Aman \\
\hline & April & 13 & Aman \\
\hline & Mei & 45 & Aman \\
\hline & Juni & 69 & Aman \\
\hline & Juli & 8 & Aman \\
\hline & \multicolumn{3}{|c|}{ Total Suspended Solid (TSS) } \\
\hline & \multicolumn{2}{|c|}{ Baku Mutu } & $\begin{array}{l}\text { Kandungan } \\
\text { Maksimum }\end{array}$ \\
\hline & \multirow{2}{*}{\multicolumn{2}{|c|}{$\begin{array}{l}\text { PERGUB Bali No. } 16 / 2016 \\
\text { PERMEN LHK No } \\
\text { P.68/2016 }\end{array}$}} & 200 \\
\hline & & & 30 \\
\hline
\end{tabular}

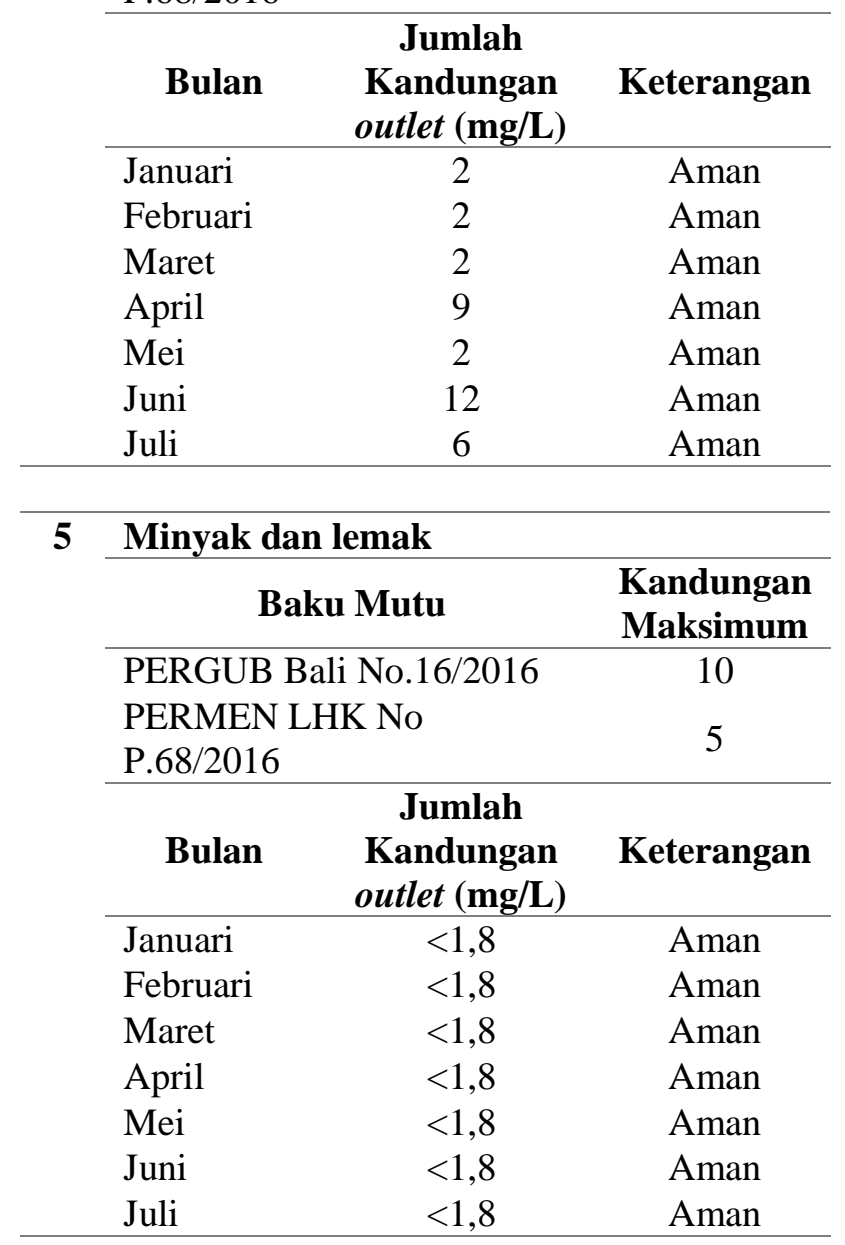

\begin{tabular}{|c|c|c|c|}
\hline \multirow[t]{13}{*}{6} & \multicolumn{3}{|l|}{ Amonia } \\
\hline & \multicolumn{2}{|c|}{ Baku Mutu } & $\begin{array}{l}\text { Kandungan } \\
\text { Maksimum }\end{array}$ \\
\hline & \multicolumn{2}{|c|}{ PERGUB Bali No.16/2016 } & \\
\hline & \multicolumn{2}{|c|}{ PERMEN LHK No } & 10 \\
\hline & \multicolumn{3}{|c|}{ P.68/2016 } \\
\hline & \multicolumn{3}{|c|}{$\begin{array}{c}\text { Kandungan } \\
\text { outlet }(\mathrm{mg} / \mathrm{L})\end{array}$} \\
\hline & Januari & 1 & Aman \\
\hline & Februari & 0,03 & Aman \\
\hline & Maret & 0,01 & Aman \\
\hline & April & 0,01 & Aman \\
\hline & Mei & 0,05 & Aman \\
\hline & Juni & 0,1 & Aman \\
\hline & Juli & 0,01 & Aman \\
\hline \multirow[t]{4}{*}{7} & \multicolumn{3}{|c|}{ Total Coliform } \\
\hline & \multicolumn{2}{|c|}{ Baku Mutu } & $\begin{array}{l}\text { Kandungan } \\
\text { Maksimum }\end{array}$ \\
\hline & \multirow{2}{*}{\multicolumn{2}{|c|}{$\begin{array}{l}\text { PERGUB Bali No.16/2016 } \\
\text { PERMEN LHK No } \\
\text { P.68/2016 }\end{array}$}} & 5000 \\
\hline & & & 3000 \\
\hline
\end{tabular}

\begin{tabular}{|c|c|c|c|}
\hline & Bulan & $\begin{array}{c}\text { Jumlah } \\
\text { Kandungan } \\
\text { outlet } \\
\text { (MPN/100mL) }\end{array}$ & Keterangan \\
\hline & Januari & 330 & Aman \\
\hline & Februari & 40 & Aman \\
\hline & Maret & 2300 & Aman \\
\hline & April & 36 & Aman \\
\hline & Mei & 2700 & Aman \\
\hline & Juni & 4 & Aman \\
\hline & Juli & 1500 & Aman \\
\hline \multirow[t]{11}{*}{8} & Suhu & & \\
\hline & \multicolumn{2}{|c|}{ Baku Mutu } & $\begin{array}{c}\text { Suhu } \\
\text { Maksimum }\end{array}$ \\
\hline & \multicolumn{2}{|c|}{ PERGUB Bali No.16/2016 } & $38^{\circ} \mathrm{c}$ \\
\hline & Bulan & $\begin{array}{c}\text { Suhu di outlet } \\
\left({ }^{\circ} \mathrm{c}\right)\end{array}$ & Keterangan \\
\hline & Januari & 27 & Aman \\
\hline & Februari & 27 & Aman \\
\hline & Maret & 27 & Aman \\
\hline & April & 28 & Aman \\
\hline & Mei & 27 & Aman \\
\hline & Juni & 27 & Aman \\
\hline & Juli & 27 & Aman \\
\hline
\end{tabular}




\begin{tabular}{|c|c|c|c|}
\hline \multirow[t]{3}{*}{9} & \multicolumn{3}{|c|}{ Total Dissolved Solid (TDS) } \\
\hline & \multicolumn{2}{|c|}{ Baku Mutu } & $\begin{array}{l}\text { Kandungan } \\
\text { Maksimum }\end{array}$ \\
\hline & PERGUB & No. $16 / 2016$ & 2000 \\
\hline & Bulan & $\begin{array}{c}\text { Jumlah } \\
\text { Kandungan } \\
\text { outlet }(\mathrm{mg} / \mathrm{L})\end{array}$ & Keterangan \\
\hline & Januari & 1367 & Aman \\
\hline & Februari & 988 & Aman \\
\hline & Maret & 824 & Aman \\
\hline & April & 1604 & Aman \\
\hline & Mei & 1274 & Aman \\
\hline & Juni & 969 & Aman \\
\hline & Juli & 494 & Aman \\
\hline
\end{tabular}

10 Detergen

\begin{tabular}{lcc}
\hline \multicolumn{2}{c}{ Baku Mutu } & $\begin{array}{c}\text { Kandungan } \\
\text { Maksimum }\end{array}$ \\
\hline PERGUB Bali No.16/2016 & 10 \\
\hline Bulan & $\begin{array}{c}\text { Jumlah } \\
\text { Kandungan } \\
\text { outlet }(\mathbf{m g} / \mathbf{L})\end{array}$ & Keterangan \\
\hline Januari & 0,01 & Aman \\
Februari & 0,04 & Aman \\
Maret & 0,02 & Aman \\
April & 0,03 & Aman \\
Mei & 0,01 & Aman \\
Juni & 0,01 & Aman \\
Juli & 0,01 & Aman \\
\hline
\end{tabular}

Tabel 3 menunjukkan bahwa kandungan dari outlet IPAL RSD Mangusada tahun 2020 sudah sesuai dan memenuhi paramerer $\mathrm{pH}$ dengan standar nilai baku mutu antara 6-9. Begitu juga dengan parameter-parameter yang lain seperti nilai konsentrasi parameter $\mathrm{BOD}_{5}$, COD, TSS, parameter minyak dan lemak, ammonia, konsentrasi parameter total coliform, nilai parameter suhu, TDS, dan konsentarasi detergent sudah sesuai dan memenuhi baku mutu air limbah baik baku mutu dari PERGUB Bali No.16/2016 maupun PERMEN LHK No P.68/2016.

Evaluasi Efektivitas Pengolahan Air Limbah pada IPAL RSD Mangusada Kabupaten Badung

Menurut Soeparman dan Suparmin (2001), data parameter air limbah inlet dan outlet digunakan dalam menghitung efektivitas pengolahan air limbah dengan menggunakan rumus umum sebagai berikut:
Keterangan:

$$
\mathrm{E}=\frac{\mathrm{S}_{0}-\mathrm{S} \times 100 \%}{\mathrm{~S}_{0}}
$$

$\mathrm{E}=$ Efektivitas pengolahan air limbah pada $\operatorname{IPAL}(\%)$

$\mathrm{S}_{0}=$ Rata-rata dari konsentrasi parameter pada inlet

$\mathrm{S}=$ Rata-rata dari konsentrasi parameter pada outlet $(\mathrm{mg} / \mathrm{L})$

Menurut Soeparman dan Suparmin (2001), kriteria efektivitas IPAL dapat dilihat pada Tabel 4.

Tabel 4. Kriteria Efektivitas Instalasi Pengolahan Air Limbah

\begin{tabular}{ccc}
\hline No & $\begin{array}{c}\text { Nilai Persentase } \\
\text { Efisiensi }\end{array}$ & Keterangan \\
\hline $\mathbf{1}$ & $\mathrm{X}>80 \%$ & $\begin{array}{c}\text { Sangat Efektif } \\
(\mathrm{SE})\end{array}$ \\
$\mathbf{2}$ & $60 \%<\mathrm{X} \leq 80 \%$ & $\begin{array}{c}\text { Efektif } \\
(\mathrm{E})\end{array}$ \\
$\mathbf{3}$ & $40 \%<\mathrm{X} \leq 60 \%$ & $\begin{array}{c}\text { Cukup Efektif } \\
(\mathrm{CE})\end{array}$ \\
$\mathbf{4}$ & $20 \%<\mathrm{X} \leq 40 \%$ & $\begin{array}{c}\text { Kurang Efektif } \\
(\text { KE) }\end{array}$ \\
$\mathbf{5}$ & $\mathrm{X} \leq 20 \%$ & $\begin{array}{c}\text { Tidak Efektif } \\
\text { (TE) }\end{array}$ \\
\hline
\end{tabular}

\section{Efisiensi Penurunan Kandungan Biological Oxygen Demand $\left(\mathrm{BOD}_{5}\right.$ ) pada Outlet IPAL}

Perhitungan efektivitas pengolahan air limbah terhadap parameter $\mathrm{BOD}_{5}$ dilakukan untuk mengetahui persentase efektivitas IPAL terhadap efisiensi penurunan kandungan $\mathrm{BOD}_{5}$. Perhitungan efisiensi penurunan kandungan $\mathrm{BOD}_{5}$ bisa dilihat pada Tabel 5 .

Tabel 5. Perhitungan efisiensi kandungan $\mathrm{BOD}_{5}$ pada outlet IPAL

\begin{tabular}{lcccc}
\hline Bulan & $\begin{array}{c}\text { Inlet } \\
(\mathbf{m g} / \mathbf{L})\end{array}$ & $\begin{array}{c}\text { Outlet } \\
(\mathbf{m g} / \mathbf{L})\end{array}$ & $\begin{array}{c}\text { Ef } \\
(\boldsymbol{\%})\end{array}$ & Ket \\
\hline Januari & 15 & 4 & 73,33 & $\mathrm{E}$ \\
Februari & 14 & 3 & 78,57 & $\mathrm{E}$ \\
Maret & 7 & 2 & 71,43 & $\mathrm{E}$ \\
April & 30 & 3 & 90 & $\mathrm{SE}$ \\
Mei & 19 & 9 & 52,63 & $\mathrm{CE}$ \\
Juni & 18 & 14 & 22,22 & $\mathrm{KE}$ \\
Juli & 5 & 2 & 60 & $\mathrm{CE}$ \\
\hline \multicolumn{5}{r}{} \\
\hline
\end{tabular}

Berdasarkan Tabel 5, rata-rata efisiensi penurunan kandungan $\mathrm{BOD}_{5}$ dari bulan Januari 2020 hingga Juli 2020 yakni 64,03\% dengan keterangan efektif. 


\section{Efisiensi Penurunan Kandungan Chemical Oxygen Demand (COD) pada Outlet IPAL}

Perhitungan efektivitas pengolahan air limbah terhadap parameter COD dilakukan untuk mengetahui persentase efektivitas IPAL terhadap efisiensi penurunan kandungan COD. Perhitungan efisiensi penurunan kandungan COD bisa dilihat pada Tabel 6 .

Tabel 6. Perhitungan efisiensi kandungan COD pada outlet IPAL

\begin{tabular}{|c|c|c|c|c|}
\hline Bulan & $\begin{array}{c}\text { Inlet } \\
(\mathrm{mg} / \mathrm{L})\end{array}$ & $\begin{array}{c}\text { Outlet } \\
(\mathrm{mg} / \mathrm{L})\end{array}$ & $\begin{array}{c}\text { Ef } \\
(\%)\end{array}$ & Ket \\
\hline Januari & 62 & 19 & 69,35 & $\mathrm{E}$ \\
\hline Februari & 56 & 13 & 76,79 & $\mathrm{E}$ \\
\hline Maret & 34 & 8 & 76,47 & $\mathrm{E}$ \\
\hline April & 119 & 13 & 89,08 & SE \\
\hline Mei & 92 & 45 & 51,09 & $\mathrm{CE}$ \\
\hline Juni & 86 & 69 & 19,77 & TE \\
\hline \multirow[t]{2}{*}{ Juli } & 23 & 8 & 65,22 & E \\
\hline & & -rat & 63,97 & fekti \\
\hline
\end{tabular}

Berdasarkan Tabel 6, rata-rata efisiensi penurunan kandungan COD dari bulan Januari 2020 hingga Juli 2020 yakni 63,97\% dengan keterangan efektif.

\section{Efisiensi Penurunan Kandungan Total Suspended Solid (TSS) pada Outlet IPAL}

TSS merupakan zat padat tersuspensi dalam air limbah yang bersifat melayanglayang dalam air (Ningsih, 2011). Perhitungan efektivitas pengolahan air limbah terhadap parameter TSS dilakukan untuk mengetahui persentase efektivitas IPAL terhadap efisiensi penurunan kandungan TSS. Perhitungan efisiensi penurunan kandungan TSS bisa dilihat pada Tabel 7.

Tabel 7. Perhitungan efisiensi kandungan TSS pada outlet IPAL

\begin{tabular}{lcccc} 
Bulan & $\begin{array}{c}\text { Inlet } \\
(\mathbf{m g} / \mathbf{L})\end{array}$ & $\begin{array}{c}\text { Outlet } \\
(\mathbf{m g} / \mathbf{L})\end{array}$ & $\begin{array}{c}\mathbf{E f} \\
(\mathbf{\%})\end{array}$ & Ket \\
\hline Januari & 34 & 2 & 94,12 & $\mathrm{SE}$ \\
Februari & 31 & 2 & 93,55 & $\mathrm{SE}$ \\
Maret & 13 & 2 & 84,62 & $\mathrm{SE}$ \\
April & 31 & 9 & 70,97 & $\mathrm{E}$ \\
Mei & 15 & 2 & 86,67 & $\mathrm{SE}$ \\
Juni & 14 & 12 & 14,29 & $\mathrm{TE}$ \\
Juli & 8 & 6 & 25 & KE \\
\hline \multicolumn{5}{r}{} \\
\hline
\end{tabular}

Berdasarkan Tabel 7 , rata-rata efisiensi penurunan kandungan TSS dari bulan Januari 2020 hingga Juli 2020 yakni 67,03\% dengan keterangan efektif.

\section{Efisiensi Penurunan Kandungan Minyak dan Lemak pada Outlet IPAL}

Perhitungan efektivitas pengolahan air limbah terhadap parameter minyak dan lemak dilakukan untuk mengetahui persentase efektivitas IPAL terhadap efisiensi penurunan kandungan minyak dan lemak. Perhitungan efisiensi penurunan kandungan minyak dan lemak bisa dilihat pada Tabel 8 .

Tabel 8. Perhitungan efisiensi kandungan minyak dan lemak pada outlet IPAL

\begin{tabular}{|c|c|c|c|c|}
\hline Bulan & $\begin{array}{c}\text { Inlet } \\
(\mathrm{mg} / \mathrm{L})\end{array}$ & $\begin{array}{c}\text { Outlet } \\
(\mathrm{mg} / \mathrm{L})\end{array}$ & $\begin{array}{l}\text { Ef } \\
(\%)\end{array}$ & Ket \\
\hline Januari & $<1,8$ & $<1,8$ & - & - \\
\hline Februari & 7 & 1,8 & 74,29 & $\mathrm{E}$ \\
\hline Maret & 4 & 1,8 & 55 & $\mathrm{CE}$ \\
\hline April & $<1,8$ & $<1,8$ & - & - \\
\hline Mei & $<1,8$ & $<1,8$ & - & - \\
\hline Juni & $<1,8$ & $<1,8$ & - & - \\
\hline Juli & $<1,8$ & $<1,8$ & - & - \\
\hline
\end{tabular}

Berdasarkan Tabel 8, rata-rata efisiensi penurunan kandungan minyak dan lemak dari bulan Februari 2020 dan Maret 2020 yakni $64,64 \%$ dengan keterangan efektif. Nilai efektivitas bulan Januari, April, Mei, Juni dan Juli tidak bisa diidentifikasi nilai efisiensinya karena sebelum pada bagian inlet dan outlet IPAL kandungan minyak dan lemak sangat kecil yakni $<1,8 \mathrm{mg} / \mathrm{L}$.

\section{Efisiensi Penurunan Kandungan Amonia pada Outlet IPAL}

Perhitungan efektivitas pengolahan air limbah terhadap parameter amonia dilakukan untuk mengetahui persentase efektivitas IPAL terhadap efisiensi penurunan kandungan amonia. Perhitungan efisiensi penurunan kandungan amonia bisa dilihat pada Tabel 9. 
Tabel 9. Perhitungan efisiensi kandungan amonia pada outlet IPAL

\begin{tabular}{|c|c|c|c|c|}
\hline Bulan & $\begin{array}{c}\text { Inlet } \\
(\mathrm{mg} / \mathrm{L})\end{array}$ & $\begin{array}{c}\text { Outlet } \\
(\mathrm{mg} / \mathrm{L})\end{array}$ & $\begin{array}{c}\text { Ef } \\
(\%)\end{array}$ & Ket \\
\hline Januari & 38 & 1 & 97,37 & SE \\
\hline Februari & 34 & 0,03 & 99,91 & SE \\
\hline Maret & 28 & 0,01 & 99,96 & $\mathrm{SE}$ \\
\hline April & 34 & 0,01 & 99,97 & SE \\
\hline Mei & 0,1 & 0,05 & 50,00 & $\mathrm{CE}$ \\
\hline Juni & 14 & 0,1 & 99,29 & SE \\
\hline Juli & 24 & 0,01 & 99,96 & SE \\
\hline \multicolumn{3}{|c|}{ Rata-rata } & 92,35 & $\begin{array}{l}\text { Sangat } \\
\text { Efektif }\end{array}$ \\
\hline
\end{tabular}

Berdasarkan Tabel 9, rata-rata efisiensi penurunan kandungan amonia dari bulan Januari 2020 hingga Juli 2020 yakni 92,35\% dengan keterangan sangat efektif.

\section{Efisiensi Penurunan Kandungan Total Coliform pada Outlet IPAL}

Bakteri Escherichia coli merupakan bakteri yang dapat dijadikan indikator polusi buangan manusia (Sari, 2015). Perhitungan efisiensi penurunan kandungan total coliform bisa dilihat pada Tabel 10 .

Tabel 10. Perhitungan efisiensi kandungan total coliform pada outlet IPAL

\begin{tabular}{|c|c|c|c|c|}
\hline \multirow{2}{*}{ Bulan } & Inlet & Outlet & Ef & Ket \\
\hline & \multicolumn{2}{|c|}{ (MPN/100mL) } & $(\%)$ & \\
\hline Januari & 4000 & 330 & 91,75 & SE \\
\hline Februari & 9100 & 40 & 99,56 & SE \\
\hline Maret & 9100 & 2300 & 74,73 & E \\
\hline April & 92000 & 36 & 99,96 & SE \\
\hline Mei & 4300 & 2700 & 37,21 & $\mathrm{KE}$ \\
\hline Juni & 4300 & 4 & 99,91 & SE \\
\hline \multirow[t]{2}{*}{ Juli } & 2300 & 1500 & 34,78 & $\mathrm{KE}$ \\
\hline & \multicolumn{2}{|c|}{ Rata-rata } & 76,84 & Efektif \\
\hline
\end{tabular}

\section{Efisiensi Penurunan Kandungan Detergen pada Outlet IPAL}

Perhitungan efektivitas pengolahan air limbah terhadap parameter detergen dilakukan untuk mengetahui persentase efektivitas IPAL terhadap efisiensi penurunan kandungan detergen. Perhitungan efisiensi penurunan kandungan detergen bisa dilihat pada Tabel 11:
Tabel 11. Perhitungan efisiensi kandungan detergen pada outlet IPAL

\begin{tabular}{|c|c|c|c|c|}
\hline Bulan & $\begin{array}{c}\text { Inlet } \\
(\mathrm{mg} / \mathrm{L})\end{array}$ & $\begin{array}{c}\text { Outlet } \\
(\mathrm{mg} / \mathrm{L})\end{array}$ & $\begin{array}{c}\text { Ef } \\
(\%)\end{array}$ & Ket \\
\hline Januari & 0,2 & 0,01 & 95 & SE \\
\hline Februari & 0,2 & 0,04 & 80 & $\mathrm{E}$ \\
\hline Maret & 0,1 & 0,02 & 80 & E \\
\hline April & 0,06 & 0,03 & 50 & CE \\
\hline Mei & $<0,01$ & $<0,01$ & - & - \\
\hline Juni & $<0,01$ & $<0,01$ & - & - \\
\hline Juli & $<0,01$ & $<0,01$ & - & - \\
\hline
\end{tabular}

Berdasarkan Tabel 11, rata-rata efisiensi penurunan kandungan detergen dari bulan Januari 2020 hingga April 2020 yakni 76,25\% dengan keterangan efektif. Nilai efektivitas bulan Mei, Juni dan Juli tidak bisa diidentifikasi nilai efisiensinya karena sebelum pada bagian inlet dan outlet IPAL kandungan detergen sangat kecil yakni $<0,01 \mathrm{mg} / \mathrm{L}$.

\section{Efisiensi Penurunan Kandungan Total Dissolve Solid (TDS) pada Outlet IPAL}

Perhitungan efektivitas pengolahan air limbah terhadap parameter TDS dilakukan untuk mengetahui persentase efektivitas IPAL terhadap efisiensi penurunan kandungan TDS. Perhitungan efisiensi penurunan kandungan TDS bisa dilihat pada Tabel 12 .

Tabel 12. Perhitungan efisiensi kandungan TDS pada outlet IPAL

\begin{tabular}{|c|c|c|c|c|}
\hline Bulan & $\begin{array}{c}\text { Inlet } \\
(\mathrm{mg} / \mathrm{L})\end{array}$ & $\begin{array}{l}\text { Outlet } \\
(\mathrm{mg} / \mathrm{L})\end{array}$ & $\begin{array}{l}\text { Ef } \\
(\%)\end{array}$ & Ket \\
\hline Januari & 1864 & 1367 & 26,66 & $\mathrm{KE}$ \\
\hline Februari & 1154 & 988 & 14,38 & TE \\
\hline Maret & 999 & 824 & 17,52 & TE \\
\hline April & 1589 & 1604 & $-0,94$ & TE \\
\hline Mei & 1345 & 1274 & 5,28 & TE \\
\hline Juni & 400 & 969 & $-142,25$ & TE \\
\hline Juli & 1027 & 494 & 51,90 & $\mathrm{CE}$ \\
\hline \multicolumn{3}{|c|}{ Rata-rata } & ,92 & $\begin{array}{c}\text { Tidak } \\
\text { Efektif }\end{array}$ \\
\hline
\end{tabular}

Berdasarkan Tabel 12, rata-rata efisiensi penurunan kandungan TDS dari bulan Januari 2020 hingga Juli 2020 yakni $-3,92 \%$ dengan keterangan tidak efektif.

\section{Pembahasan}

Berdasarkan hasil perbandingan kualitas air limbah pada outlet IPAL RSD Mangusada terhadap PERGUB Bali No. 16 Tahun 2016 tentang baku mutu lingkungan hidup dan kriteria baku kerusakan lingkungan hidup serta 
PERMEN LHK Republik Indonesia Nomor: P.68/Menlhk/Setjen/Kum.1/8/2016 tentang baku mutu air limbah domestik, didapat hasil bahwa parameter $\mathrm{pH}, \mathrm{BOD}_{5}, \mathrm{COD}, \mathrm{TSS}$, minyak dan lemak, amonia, total coliform, suhu, TDS dan detergen pada bagian outlet memenuhi syarat-syarat dari peraturan baku mutu yang menjadi acuan.

Ditinjau dari efektivitas kinerja IPAL RSD Mangusada Kabupaten Badung terhadap penurunan kandungan $\mathrm{BOD}_{5}, \mathrm{COD}$, TSS, minyak dan lemak, amonia, total coliform, TDS dan detergen di bagian outlet bisa dilihat pada gambar 3 .

\section{Persentase efisiensi penurunan kandungan tiap parameter terhadap outlet IPAL (\%)}

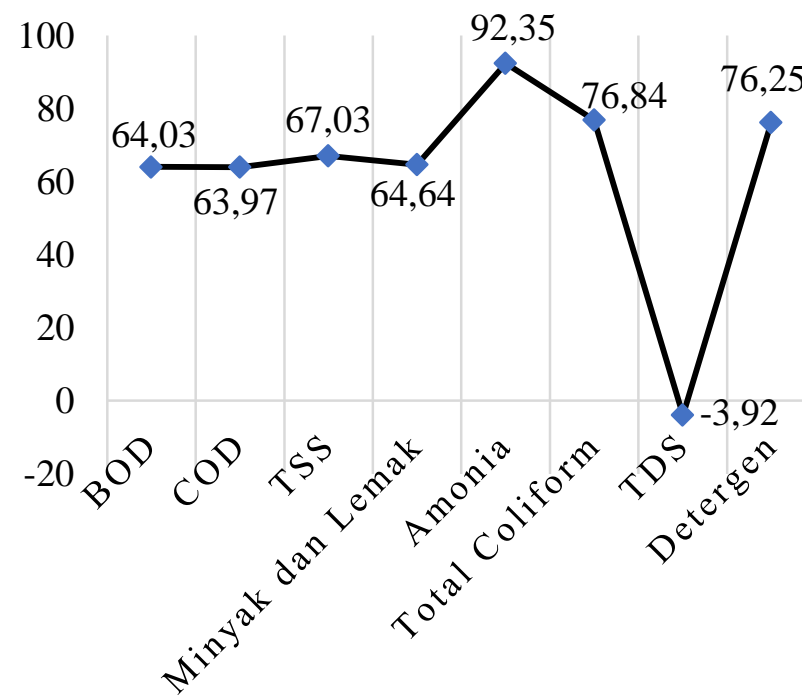

Gambar 3. Grafik persentase efisiensi penurunan kandungan tiap parameter terhadap outlet IPAL

Efektivitas IPAL RSD Mangusada Kabupaten Badung tergolong baik, efisiensi penurunan kandungan amonia $92,35 \%, \mathrm{BOD}_{5}$ $64,03 \%$, COD 63,97\%, TSS 67,03\%, minyak dan lemak $64,64 \%$, total coliform $76,84 \%$, dan detergen sebesar 76,25\%. Tetapi efektivitas IPAL RSD Mangusada Kabupaten Badung kurang baik dalam penurunan kandungan TDS, karena efisiensi penurunan nilai dari konsentrasi kandungan TDS sebesar $-3,92 \%$. sehingga dapat disimpulkan bahwa unit pengolahan air limbah menggunakan sistem biofilter tidak efektif untuk efisiensi penurunan kandungan TDS. Efisiensi penurunan kandungan TDS terhadap kinerja IPAL dengan sistem biofilter dikategorikan tidak efektif karena unit pengolahan air limbah yang dirancang dengan sistem biofilter masih kurang optimal, hal ini terjadi bisa disebabkan oleh unit anaerobic processor dan reaktor biofilter yang dilengkapi dengan filter berupa media plastik piramid belum mampu menyaring padatan organik yang berukuran sangat kecil sehingga pengolahan air limbah dengan sistem biofilter dikatakan tidak efektif untuk menurunkan kandungan TDS pada air limbah.

\section{SIMPULAN}

1. Parameter $\mathrm{pH}, \mathrm{BOD}_{5}, \mathrm{COD}$, TSS, minyak dan lemak, amonia, total coliform, suhu, TDS dan detergen pada bagian outlet telah memenuhi syarat-syarat baku mutu dari PERGUB Bali No. 16 Tahun 2016 tentang baku mutu lingkungan hidup dan kriteria baku kerusakan lingkungan hidup serta PERMEN LHK Republik Indonesia Nomor: P.68/Menlhk/Setjen/Kum.1/8/ 2016 tentang baku mutu air limbah domestik.

2. Efektivitas IPAL RSD Mangusada Kabupaten Badung tergolong baik, efisiensi penurunan kandungan amonia 92,35\%, $\mathrm{BOD}_{5} 64,03 \%$, COD 63,97\%, TSS $67,03 \%$, minyak dan lemak $64,64 \%$, total coliform 76,84\%, dan detergen sebesar 76,25\%. Tetapi efektivitas IPAL RSD Mangusada Kabupaten Badung kurang baik dalam penurunan kandungan TDS, karena efisiensi penurunan nilai dari konsentrasi kandungan TDS sebesar $3,92 \%$.

\section{SARAN}

Adapun saran atau solusi dalam mengevaluasi kinerja IPAL pada RSD Mangusada Kabupaten Badung:

1. Perlu adanya pemantauan kinerja IPAL setidaknya tiap 1 bulan sekali setelah hasil dari uji sampel air limbah RSD Mangusada dari PT. Unilab Perdana keluar. Tindakan pemantauan terhadap kinerja IPAL berguna untuk mengetahui tingkat efisiensi dari kinerja IPAL terhadap kandungan yang terdapat pada air limbah.

2. Perlu adanya penambahan kapasitas IPAL berhubung dengan adanya penambahan gedung-gedung baru pada RSD Mangusada Kabupaten Badung. 


\section{DAFTAR PUSTAKA}

Ayuningtyas, R. D. 2009. Proses Pengolahan Limbah Cair Di Rsud Dr. Moewardi Surakarta. Hiperkes. Hal: 1-59.

Djaja, I. M., dan Maniksulistya, D. 2006. Gambaran Penglolaan Limbah Cair Di Rumah Sakit X Jakarta Februari 2006. Makara, Kesehatan. Hal: 60-63.

Kementerian Lingkungan Hidup dan Kehutanan RI. 2016. Peraturan Menteri Lingkungan Hidup Dan Kehutanan Republik Indonesia Nomor: P.68/Menlhk/Setjen/Kum.1/8/2016

Tentang Baku Mutu Air Limbah Domestik.

Keputusan Menteri Kesehatan RI. 2004. Keputusan Menteri Kesehatan Republik Indonesia Nomor: 1204/Menkes/Sk/X/ 2004 Tentang Persyaratan Kesehatan Lingkungan Rumah Sakit. Hal: 12-13.

Mulyati, M., dan Narhadi, J. S. 2016. Evaluasi Instalasi Pengolahan Air Limbah Rumah Sakit RK Charitas Palembang. Hal: 66-67.

Ningrum, T., dan Khalista, N. 2014. Gambaran Pengelolaan Limbah Cair Di Rumah Sakit X Kabupaten Jember. Hal: $1-12$.

Ningsih, R. 2011. Pengaruh Pembubuhan Tawas Dalam Menurunkan TSS Pada Air Limbah Rumah Sakit. Hal: 80.

Peraturan Gubernur Bali. 2016. Peraturan Gubernur Bali No. 16 Tahun 2016 Tentang Baku Mutu Lingkungan Hidup Dan Kriteria Baku Kerusakan Lingkungan Hidup. Hal: 1-8.

RSD Mangusada. 2019. Buku Profil Rsd Mangusada.

RSD Mangusada. 2020. Buku data kualitaskuantitas air limbah dan kapasitas IPAL RSD Mangusada Kabupaten Badung.

Sari, D. R. 2015. Evaluasi Pengolahan Air Limbah Dengan Sistem Extended Aeration Di Rumah Sakit " $X$ ” Semarang. Hal: 164.

Soeparman dan Suparmin, 2001. Pembuangan Tinja dan Limbah Cair. Buku Kedokteran EGC. Jakarta.

Subekti, S. 2011. Pengaruh Dan Dampak Limbah Cair Rumah Sakit Terhadap Kesehatan Serta Lingkungan. Jurnal Universitas Pandanaran, Hal: 1-6.

Yenti, S. 2011. Evaluasi Instalasi Pengolahan Air Limbah (IPAL) Rumah Sakit (Studi
Kasus: Rumah Sakit St. Carolus Jakarta). Hal: 62-63. 